\title{
OOR DIE KONINKRYK VAN GOD
}

\section{Die Koninkryk van God in die Ou Testament.}

As Johannes die Doper spreek van die koninkryk van God wat naby gekom het (Matt. $3: 12$ ) en Jesus dat die koninkryk inderdaad gekom het (Matt. 12 : 28; Luk. $11: 20 ; 17: 21$ ), spreek hulle oor 'n saak wat eers ver was en nou naby is, en wat eers nie was nie of elders was en nou gekom het.

Voor die koms van die Messias het die koninkryk dus nie gekom nie; nie na die aarde gekom nie en het dit in die ou verbond nie op aarde bestaan nie. Tog is daar in die Ou Testament by die begrip malkoet Jahwé sprake van 'n bestaande koninkryk en heerskappy van God oor alle geskapene. Van hierdie koningskap en heerskappy spreek bv. Num. $23: 21$; I Kon. 22 : 19; Jes. $6: 5$; die heerskappy is openbaring van God se almag; die ryk het onderdane (Ps. $47: 8$, 9), die mens kan hom daaraan onderwerp (Ps. $99: 5$ ), maar die heerskappy bestaan onafhanklik van die onderdane en die onderwerping. Die heerskappy van God is suiwer geleë in sy almag wat oor alle dinge gaan. (Ps. $103: 19$ ). 
Maar hierdie malkoet Jahwê, wat 'n almagtige heerskappy van God oor die skepping is, is nie dieselfde saak as die basileia tou Theou (Koninkryk van God) of ouranou (van die hemel) nie, want allereers is dit 'n saak wat is en nie nog moet kom nie en aan die almagsheerskappy van God drieënig verander hoegenaamd niks as die ou in die nuwe verbond oorgaan nie.

In die O.T. is daar egter ook sprake van 'n koninkryk wat nog moet kom en wat nie met die almagsheerskappy van God verwar moet word nie. Hierdie koninkryk het betrekking op die gelowiges. Israel, die straf wat die volk uit die hand van die Here ondergaan, die heerlike herstel, die koms van die Messiaskoning en die oorwinning oor die heidenssondige-magskonsentrasies, wat ons as die ryk van die duiwel moet sien; die koms van die koninkryk word voorafgegaan deur die jom Jahwê, die dag van gerig, en dit loop uit op 'n ewige heerlikheid, die regnum gloriae.

Die dag van gerig gaan ook oor Israel (Am. $2: 4 ; 5: 16 ;$ Hos. $1: 6 ; 2: 11 ; 3: 4$ ens.). Die straf is tydelik (Jes. $27: 7$ e.v.; Jer. 30 : 11; Jes. 54 : 7, 8 ens.); aan die einde van die straf stuur die Here die Messias wat 'n ryk van geregtigheid en vrede kom stig (Jes. 11 : 4066; Am. 9 : 11; Hos. 1 : 11; 3 : 5; Eseg. 34 : 23, 24 ens.); tot die weldade wat die Gesalfde aan sy volk sal skenk, hoort die terugkeer uit die ballingskap (Jes. $35: 1-9 ; 41: 17-20$ ens.), bekering — 'n heilige oorblyfsel is 'n heilige volk met God as Koning (Hos. 1 : 10, 12; Jes. $4: 3,4 ; 11: 9$ ens.), die tempel en die erediens word herstel (Jes. $28: 16 ; 30: 19 ; 35: 5$ ens.), stoflike seëninge bly nie uit nie (Hos. 2 : 17; Miga 5 : 9; Jes. 2 : 4 ens.), gestorwe Israeliete deel in die seën (Hos. $6: 2$; Jes. $25: 8$; $26: 19$; Eseg. $37: 1$ 4; Dan. $12: 2$ ) en die heerskappy van die Messias sal hom oor alle volkere uitbrei (Ps. $2,21,24,45,89,98$, Jes. $17: 7$ en $19: 18$ ).

Die koms van die Messias en die koninkryk en die daarmee ge. paardgaande oorwinning oor die vyande van God en van Israel, dit is die ryk van die duiwel, word hoofsaaklik gesien as 'n toekomstige saligheid op aarde. Die O.T. ken byna uitsluitlik slegs een koms van die Messias en die koninkryk; byna altyd gryp die profesieë na die einde, na die glorieryk van die Drieënige God. En tog is daar ook sprake van die Messiasheerskappy, naamlik dat God in die midde van sy volk sal woon en dat die sentrum van die godsregering verplaas word na Sion.

Uit die N.T. weet ons dat die koms van die Messias en die koninkryk en die oorwinning oor die duiwel in twee dele uiteen val. 
Opsommend kan ons die volgende stel oor die koninkryk van God in die O.T.:

a. Die K.G. beklee 'n betreklik ondergeskikte rol as gedink word aan die sentrale posisie van die begrip basileia (koninkryk) in die N.T.

b. Die K.G. kom veelal neer op 'n eienskap van God, naamlik sy mag en majesteit; malkoet word dan vertaal met koningskap.

c. Die K.G. is in die O.T. baie meer kosmies bepaal as geestelik, d.w.s. dit word ideëel gesien as die voltooide ryk van die heerlikheid.

d. Die O.T. ken die K.G. slegs as 'n toekomstige realiteit.

Op grond van die voorgaande is dit nodig om sekere onderskeidinge te maak waarop later teruggekom word en wat ook verder gefundeer sal word.

a. Die stigting van die K.G. val saam met die skepping, en die ryk omvat die ganse skepping. God is daarvan die absolute Soewerein en sy almag strek hom daar absoluut oor uit, sodat selfs die sondige kringe op aarde en die duiwel en sy mag in die graf en die hel daaraan onderworpe is.

b. Die heerskappy van God het egter twee duidelike onderskeie kante:

1. God heers deur sy uitwendige mag regstreeks, onmiddellik en absoluut oor die stoflike skepping.

2. Die skepping het egter ook 'n geestelike sy, naamlik die engele en die mens as geestelike wesens; ook hierdie sy van die skepping is onderworpe aan die uitwendige magsheerskappy van God. maar God regeer dit ook deur die sedelike bestaan van die geestelike deel van die skepping. D.w.s. die engele en die mens is deur God geskape om hulle uit hulleself in absolute gehoorsaamheid aan God te onderwerp. Hierdie geestelike heerskappy van God deur sy sedelike wêreldorde word in die N.T. die basileia tou Theou of ouranou genoem en word in die O.T. verwag en in vooruitsig gestel.

3. Die val van die engele en die mens het in hierdie geestelike heerskappy van God in die hart of van die koninkryk van God 'n breuk geslaan, sodat dit in die hemel tot 'n absolute skeiding gekom het, nl. die goeie engele het die basileia bly vorm en die slegte engele het die ryk van die duiwel geword.

c. Op aarde het dit nie tot 'n skeiding gekom nie maar tot 'n botsing tussen die koninkryk van die hemele of van God en die koninkryk van die duiwel; die een werk vanuit die hemel kragtens die uitver'iesing geestelik om die mens weer terug te voer na dieselfde 
standpunt as van die goeie engele in die hemel; die ander werk onheilig om die mens in sy hart, geestelik, by die hel en die ryk van die duiwel in te lyf.

d. In die O.T. bestaan hierdie koninkryk uitsluitlik in die hemel en word van daaruit die voorbereiding getref vir die koms van die K.G. na die aarde met die koms van die Messias wat ook sal beteken die oorwinning oor die ryk van die duiwel.

Met die sondeval is die K.G. dus in die hemel teruggetrek of God het dit tot die hemel beperk, en bestaan dit nie meer op aarde nie. Ten besluite nog 'n enkele woord oor die posisie van Israel in hierdie K.G. Die koninkryk van Israel was 'n voorafskaduwing en 'n tipiese voorstelling van die K.G. Die koninkryk van Israel was daarom bestem om te verdwyn sodra die ware K.G. op aarde sou kom. Verder was Israel ook tipe en voorafskaduwing van die ewige regnum gloriae (ryk van heerlikheid).

2. Die Koninkryk van God in die Nuwe Testament.

A. Die koningskap van Christus.

In die N.T. moet by die behandeling van die begrip basileia tou Theou of ouranou gesoek word na die koninkryk wat gekom het of nog moet kom. Van groot belang is daarvoor die nou band wat in die O.T. gelê word tussen die komende Messias en die komende koninkryk. Eers moet dus behandel word die koningskap van die Messias, nl. is Jesus Koning? Hoe ver strek die koningskap hom uit? Is Hy alleen Koning van die kerk of ook van die ganse skepping? Wat is die verhouding tussen Christus die Koning en God die Koning, en later, tussen die ryk van Christus en die ryk van God.

a. Christus is Koning -. Skriftuurplekke.

Luk. 1 : 32, 33; Matt. 2 : $2 ; 4$ : 17; Luk. 1 : 35; 3 : 22; Joh. 1 : 32; Matt. 3 : 16; Mark. 1 : 10; Matt. 13 : 11, 24, 31; $25: 1$; 25 : 31 e.v.; 26 : 64 en Joh. 18 : 36 e.v.; $19: 19 ; 2$ : 11; na die opstanding Matt. 28 : 18; Rom. $14: 7--9 ; 14: 17$; 1 Kor. 15 : 24, 25; Ef. 1 : 22;

Filip. $3: 21 ; 1$ Petr. $3: 22$; baie plekke in Openbaringe.

Psalm 110: 1 word telkens weer aangehaal in die evangelies, Handelinge, briewe van Paulus, Hebreërs en Openbaringe. Die gedagte vorm 'n sentrale en gemeenskaplike belydenis van die N.T. skrywers; en dit verteenwoordig 'n stellige heenwysing na die feit dat Jesus die goddelike troon bestyg het, dat $\mathrm{Hy}$ inderdaad die Koning is. 
b. Die karakter van die koningskap.

1. Uit die genoemde plekke en nog ander is dit duidelik dat die koningskap van Christus nie 'n wesensmag is nie maar 'n mag wat Hom, as die Messias, verleen of gegee is. Die Vader het Hom tot Koning verordineer, Hom daartoe met die Heilige Gees gesalf en Hom die mag gegee (vgl. Kategismus); en dit sê Jesus ook met nadruk in Matt. 28 : 18: „Aan My is gegee alle..."

2. Die koningskap van Jesus wat $\mathrm{Hy}$ as Middelaar beklee, amptelik beklee, moet skerp onderskei word van sy koninklike heerskappy of mag as die tweede Persoon in die goddelike Drieëenheid. Met die Vader en die H.G. is Hy waaragtige en ewige God en "deel" $\mathrm{Hy}$ in die goddelike mag oor die ganse heelal. Hierdie mag is wesensmag en hoef Hom nie gegee te word nie en dit gaan ook ver uit bo die verworwe en verkreë koningsheerskappy wat Christus kragtens sy middelaarswerk besit.

3. Christus ontvang die kroon as loon op sy middelaarswerk, sy absolute gehoorsaamheid (Filip. $2: 8-11$ ). Hierdie loon is nie alleen bekroning van die lydenswerk nie maar ook 'n noodsaaklike element in die middelaarswerk, want daardeur moet $\mathrm{Hy}$ die werk voltooi, naamlik deur dié mag moet $\mathrm{Hy}$ in hierdie wêreld die K.G. in volkomenheid laat kom.

Die saak is naamlik só: In die skepping word alle dinge aan die mens onderwerp, hy heers amptelik as koning en is self vrywillig in absolute gehoorsa3mheid aan God onderworpe - dit is God se geestelike heerskappy of die K.G. Die mens is egter ongehoorsaam. Eers die Mens Christus is weer absoluut gehoorsaam (kragtens sy Godheid); alles word aan Hom onderwerp en $\mathrm{Hy}$ heers as Koning, almagtig kragtens sy Godheid.

4. Christus is Koning ook voor sy verhoging, vgl. Skriftuurplekke.

5. Die koningskap van Christus is geestelik van aard, van hemelse, bo-tydse struktuur, Joh. 18 : 36: „My koninkryk is nie van hierdie wêreld nie; 1 Tim. $6: 13$ en Luk. $17: 20$ : „Die K.G. kom nie met sigbare tekens nie".

Dit wil egter nie sê dat sy koningskap met die wêreld of die mens niks te doen het nie. Christus spreek duidelik oor sy heerskappy: My koninkryk is nie van hier nie, maar tog is dit hier, bv. Luk. $17: 21$.

Die geestelike karakter hou in dat dit in sy oorsprong nie van die aarde nie maar uit die hemel is; dit bedien hom nie van 
aardse nie maar van geestelike en hemelse middele, al voer Christus die koningskap ook uit deur die diens van mense. Alle verwêreldliking van die koningskap moet dus afgewys word. Die wêreld word wel nie positief deur Christus geregeer nie, maar dit staan tog absoluut onder sy mag, dit is aan Hom onderworpe en dit sal Hom eindelik, by sy wederkoms, as Here erken en huldig.

c. Die uitoefening van die koningskap.

1. Die koningskap van Christus is mag, heerskappy wat die Vader Hom gegee het. Christus is die Koning van die koninkryk van God onderworpe aan die Vader. So kan ons ook spreek van die koninkryk van Christus.

2. In die koningskap van Christus onderskei ons die regnum potentiae (potestatis) en die regnum gratiae.

Regnum potentiae is sy mag oor die ganse skepping. Regnum gratiae is sy heerskappy in sy kerk en op elke terrein wat $\mathrm{Hy}$ vir Hom opeis en waar Hy wil dat sy ryk sal kom. Dit is slegs 'n onderskeiding en geen skeiding nie en die eerste is aan die tweede ondergeskik (Ef. $1: 22$ ), want Jesus het alle mag ontvang (potentiae) nie om die Vader te vervang nie, maar om Koning oor sy volk te wees, hulle te vergader en te beskerm en van hulle uit die genadeheerskappy uit te brei en sy koninkryk in volkomenheid te laat kom.

3. Hoe Christus sy mag in die regnum potentiae nou uitoefen is 'n saak waarop ons nie in hierdie artikel kan ingaan nie (met die oog op wêreldtoestande sou dit baie interessant wees om hieroor van iemand 'n artikel te kry); tydens sy omwandelinge merk ons dit in sy mag oor die duiwels, krankheid, die natuur ens. Sy koningskap in die regnum gratiae is duidelik openbaar in sy regering oor sy gemeente waarvan $\mathrm{Hy}$ die Hoof maar ook die Koning is. Die regnum gratiae bestaan binne die instituut van die kerk maar ook daarbuite; Christus is ook Koning oor die staat, samelewing, wetenskap ens.

B. Die koninkryk van God teenwoordige realiteit.

a. Die koninkryk van God het naby gekom.

Ons moet eers vasstel wat die uitspraak ,die K.G. het naby gekom" heteken. Die Skriftuurplekke is: Matt. $3: 2 ; 4: 17 ; 10: 7$; Mark. 1 : 15; Luk. $10: 9$. 
Hierdie aankondiging het aangesluit by die O.Tiese koninkryksverwagting en die mense wis min of meer waaroor Johannes en Jesus gepraat het. Ons voel dat die volk wat die belofte van die K.G. ontvang het, bv. Jes. $61: 6$, nie anders kon dink nie as dat die dag van heil vir Israel begin aan te lig as hulle meegedeel word dat die tyd vervul is en die K.G. naby gekom het.

By Johannes gaan hierdie aankondiging gepaard met die streng eis tot bekering omdat dit aansluit by die O.Tiese gerigsaankondiging, nl. dat die gerig die koms van die K.G. voorafgaan. Jesus stel nie allereers die gerig nie, maar die blye boodskap van die verlossing. Die werkwoord engizein - engiken hê basileia tou Theou - word met "naby gekom" vertaal en nie met bv. „naderby" nie (dit sou ook in die lyn van die ewolusiegedagte lê, nl. dat die mens 'n skrede

naderby sou gekom het aan bereiking van volkomenheid). Naby bly naby, d.w.s. wat nog skaduwee was word werklikheid, profesie word vervulling, tipe word waarheid, woord word feit.

Vanweë sy gebruik en ook die verband moet engiken ruimtelik gedink word, hoewel dit ook gedeeltelik tydelik gesien kan word. Dus só dat die K.G. vanuit die hemel in hierdie wêreld gekom het en nou as presente waarheid en werklikheid op aarde is. „Naby gekom" gaan dus om 'n openbaarwording van die K.G. en nie 'n ontstaan daarvan nie.

In hierdie verband moet as versterking dien die tekste Luk. 11 : 20 en Matt. 12 : 28, nl, dat die K.G. het gekom, ephthasen. Phthanein moet deur die gebruik en die verband uitsluitlik ruimtelik gesien word. In die verband sluit die "nabygekom" en die "gekom het" aan, verbind deur die koninklike wondermag van Jesus.

b. Die koninkryk van God het gekom (ephthase).

1. Allereers predik Jesus die teenwoordige realiteit van die K.G. in die prediking van sy oorwinning op die duiwel, Matt. $12: 28$ : „Maar as Ek deur die Gees van God by julle die duiwels uitdryf, dan het die koninkryk van die hemele by julle gekom". As Christus die duiwel bind, toon $\mathrm{Hy}$ ontwyfelbaar, ook op grond van die O.T., dat die K.G. gekom het, dat dit werklik is.

2. Matt. 11 : 12 waar ons die nuwe Nederlandse vertaling volg.

3. Luk. 17 : 21. Die K.G. entos humoon estin, is binne-in julle, of liewer, in julle midde of onder julle. (Ons volg hierdie vertaling omdat binne-in sou beteken dat die K.G. in die hart van die 
Fariseërs sou wees, iets wat ons uit die verband nie met reg kan konkludeer nie. In julle midde of onder julle pas dan beter omdat dit sou sien op die gelowiges, die dissipels, wat daar by die Fariseërs staan, saam met hulle Koning, Jesus).

4. Ander direkte uitsprake wat vir hulleself spreek is: Matt. 23 : 13; Mark. 4 : 26-29; $10: 15$; Luk. $10: 1$; Rom. $14: 17$; 1 Kor. $4: 20 ; 1$ Thes. $1: 12$ en 2 Thes. $1: 5$.

5. 'n Drietal plekke wat spreek van 'n komende ryk moet vir die teenwoordige realiteit ondersoek word omdat daar sprake kan wees van vervulling wat reeds ingetree het: Mat. 16 : 28; Mark. $9: 1$; Luk. $9: 27$. Dié tekste sien nie op 'n spoedige wederkoms van Christus nie maar op 'n openbaring van die ryk wat deur sommige gesien sal word en wat slaan op die opstanding en die kragtige werking van die Gees deur die Evangelie na die Pinkster.

c. Die oorwinning oor die duiwel.

Hierdie saak wil ons alleen konstateer: Christus het die duiwel oorwin. Op. 12.

d. Konklusie.

Die koninkryk van God het gekom; dit is 'n praesens realiteit.

C. Die koninkryk van God toekomende realiteit.

a. Die K.G. is teenwoordig maar dit groei en ontplooi.

Naas die Skriftuurplekke wat genoem is om die praesens realiteit van die K.G. aan te dui, is daar uitsprake wat wys op die K.G. wat is maar ook groei en ontplooi en in volkomenheid eindelik kom. Van die ontplooiing spreek Jesus in gelykenisse, nl. Matt. $13: 1-\mathbf{9}$ en $18-23 ; 13: 24-30,36-43,31-33$; Mark. $4: 26-29$, wat almal as inleiding die formule het: ,die K.G. is soos..." By almal tref ons sterk die gedagte van ontwikkeling in die K.G. aan en die proses, die ontwikkeling, moet eers afgeloop wees voordat die volle ontplooiing kom: die proses van uitgestrooide saad is afgehandel, die mosterdsaad is ' $n$ volgroeide boom, die suurdeeg laat al die deeg rys, die onkruid moet wag op die oestyd - as al hierdie dinge gebeur het, is dit die einde; dan het die K.G. tot volle ontplooiing gekom.

b. Die komende en voltooide of volmaakte K.G.

Die praesens van die K.G. is die onvolkome toestand, die futurum is die voltooide toestand. Die aantal plekke wat oor die futurum spreek 
is nie gering nie. Hierby moet ons let op die nou verband tussen die komende K.G. (volkome wordende) en die wederkomende Christus.

Luk. 19 : 11 e.v. (Jesus gaan heen op 'n ver rys, hemelvaart, en Hy kom terug, sy wederkoms, sodat sy ryk openbaar kan word). Die eskatologiese rede in Matt. 24 en 25. Matt. 25 : 1 e.v. en 14 e.v. (nou verband tussen die wederkoms en K.G.), 1 Kor. $6: 9,10$; 15 : 24; $15: 50$; Gal. 5 : 21; Ef. 5 : 5 ens.

Ingang in die K.G. geskied nie deur farisese wetsonderhouding nie, wel deur bekering, geloof, wedergeboorte; dit staan oop vir die armes, verlorenes, tollenare en sondare (Matt. $5: 3 ; 9: 11,12$; 11 : 5, 28--30 ens.); dit moet voor alles gesoek word; dit veronderstel 'n beter geregtigheid as dié van die Fariseërs; dit word ook as loon voorgestel; dit is met sy hele inhoud vergewing van die sondes, die geregtigheid en die ewige lewe.

D. Die praesens-futurum realiteit van die K.G.

Die Skrifgegewens wys op 'n praesens en 'n futurum realiteit van die K.G. Soos in die O.T. bly die K.G. in die N.T. in noue samehang met die Messias. Praesens is dit selfgetuienis en futurum is dit wederkoms van Jesus.

1. Dit is duidelik dat in die N.T. die eskatologiese moment in die basileia-begrip oorheers. Alles gaan per slot van rekening om die Theodicee, die: God is God, en die vorm van die ewige regnum gloriae.

2. Nogtans is dit duidelik dat die K.G. 'n praesens realiteit is en dat dit allereers gekom het in die vertikale lyn: vanuit die hemel het dit na die aarde gekom; die heerskappy van God in Christus het hier openbaar geword. Dit blyk ook duidelik uit ons vertaling van êngiken en epfthasen, wat ons altwee ruimtelik verstaan.

In sover die K.G. teenwoordige grootheid is, is die verkondiging daarvan in Jesus se prediking sentraal as eksponent van Jesus se selfgetuienis. Eintlik moet ons spreek van autobasileia - in Christus woon die volheid van die Godheid liggaamlik; Hy heers, is Koning ook oor die kragte van die natuur en die gang van die geskiedenis.

3. Maar tegelyk verkondig Jesus en die apostels die nadering van die basileia as consummatio saeculorum (voleinding van die eeue). Die praesens en die futurum los egter nie in mekaar op 
in dié sin dat ons ná Jesus se eerste koms te doen het met 'n horisontale koms van die K.G. in volkomenheid nie. Die koms, die futurum realiteit, bly 'n vertikale koms, plotseling en katastrofaal. Dit beteken nie 'n soort dualisme nie maar wel 'n uiteenvalling van die koms van die K.G. in twee dele of momente, soos die koms van die Messias in twee dele uiteen val, naamlik dat hierdie wêreld die getuie was van God se magsopenbaring soos hy dit in die toekoms weer sal wees.

Die interim daartussen is ook K.G. Jesus beheers ook tans die gang van die dinge en Hy manifesteer sy mag en heerskappy in hierdie wêreld deur sy kerk.

4. In hierdie interim tref ons weer die horisontale lyn van die K.G. wat aangegee word in die gelykenisse wat spreek oor die ontplooiing tot eindelik volmaaktheid.

In hierdie K.G. wat horisontaal groei, heers Jesus as Koning en onderwerp ons ons as gelowiges aan sy heerskappy, maar hierby mag ons nie bly staan nie: want die K.G. wat geestelik is en in ons harte setel, openbaar hom tewens na buite in die onderwerping van die hele lewe en hele wêreld aan die eer van sy Naam en vertoon hom as 'n waaragtige ryk of heerskappy op hierdie aarde. So was dit in die paradys; so het dit geword met die koms van die Messias en so sal dit eenmaal volmaak wees op die nuwe aarde.

Vertikaal het ons dus die spanning tussen die praesens en die futurum; horisontaal word hierdie spanning opgelos deur die wete dat die K.G. is maar ook groei en uitgebrei tot eindelike volkomenheid. En daarin is óns posisie as gelowiges, Kol. 1 : 13.

3. Die omvang van die Koninkryk van God.

In die basileia-begrip het ons vertikaal die spanning tussen die praesens en die futurum, die onvolkome en volkome realiteit. Horisontaal word die spanning opgelos deur die realiteit dat die K.G. praesens is maar groei en ontwikkel na 'n eindelike volkomenheid wat vertikaal as die consummatio saeculorum gesien word.

Die Skrif sien nou die omvang van die K.G. van twee sye:

a. Ideëel vanuit die volkomenheidstoestand, dus met die klem op die vertikale lyn, as alleen omvattende die uitverkorenes. Vir hulle word horisontaal die aarde en die hemel toeberei as die toekomstige ryksgebied. Hier is hoofsaaklik die genade-aspek van Jesus se heerskappy op die oog (regnum gratiae). 
h. Reëel vanuit die onvolkomenheidstoestand met die klem op die horisontale lyn, as omvattende hemel en aarde en alle mense. Vertikaal word, gesien as consummatio saeculorum, die omvang eindelik ingekort wat die mensheid betref, om alleen die uitverkorenes te bevat. Hier is die mag- en genade-aspek van Jesus se heerskappy in balans.

4. Die plek, omvang en taak van die kerk in die K.G.

a. In Ef. 1 word van twee kringe t.o.v. Jesus gespreek. Dit is 'n deling wat die hele hoofstuk beheers.

1 : 22: En Hy het alle dinge aan sy voete onderwerp (basileia) en Hom as Hoof bo alle dinge aan die gemeente (ekklêsia) gegee. 1 : 7: In Hom het ons die verlossing deur sy bloed, die vergifnis van alle misdade (kerk), en 1 : 10: met die doel om alle dinge wat in die hemele sowel as op die aarde is onder een Hoof Christus te verenig (basileia).

1 : 22 skei hierdie kringe duidelik van mekaar en gee die omvang van die K.G. aan as die kosmos en van die kerk as die uitverkorenes.

b. In Kol. 1 word hierdie twee kringe ook aangegee met dieselfde onderskeiding. Dit is eintlik parallelle.

Christus staan dus bo alles in die K.G. In die kerk staan Christus nie alleen bo die uitverkorenes nie, $\mathrm{Hy}$ is Koning, maar $\mathrm{Hy}$ is ook een met hulle, $\mathrm{Hy}$ is die hoof en hulle die liggaam.

c. In die praesens-futurum realiteit van die K.G., reëel en ideëel gesien, kan ons nou die kerk soos volg plaas en daarvan onderskei:

1. In die hier en nou omsluit die K.G. die ganse kosmos, terwyl die kerk slegs met mense te doen het en uit die mense alleen die uitverkorenes omsluit as 'n vergadering van die uitverkorenes.

2. Die kerk is die herstelde organisme van die mensheid en dit hou op om te bestaan wanneer die K.G. oorgaan in die ewige regnum gloriae en waarvan dit dan die nuwe mensheid vorm. As sodanig is die kerk daarom praesens ' $n$ middel, 'n voorbereidingsmiddel in die hand van die koning vir die daarstelling van die volkomenheidstoestand van die K.G.

3. Die kerk as instituut het 'n institutêr beperkte omvang wat hom duidelik onderskei as 'n veel kleiner vlak as die vlak van die K.G. Die kerk is egter ook organisme, 'n energievolle lewende werksaamheid waarin die krag van die Hoof van die kerk werksaam is ver buite die institutêre grense van die kerk oor die 
hele gebied van die koninkryk om die K.G. uit te brei en die stryd teen die koninkryk van die duiwel tot finale oorwinning te voer.

5. Die plek, omvang en taak van die genadeverbond t.o.v. die K.G.

a. Uit 1 Kor. 6 blyk 'n besondere verhouding tussen die K.G. en die verbond. Paulus spreek oor die K.G. in verse 9, 10 en 11a en verwys dan ineens in vers $11 \mathrm{~b}$ na die doop, teken van die verbond. In die verband word basileia en verbond hier na die inhoud dig by mekaar gesien.

b. Rom. 4 : 10b en 11: hier is die besnydenis seël van die dikaiosune (geregtigheid) wat sinoniem is met die basileia.

c. In sy praesens realiteit word die K.G. altyd gesien teenoor die ryk van die satan as die groeiende, volkome wordende en op oorwinning afsturende heerskappy van Christus. Hierin word die mense, en met name die uitverkorenes, verbondsmatig betrek as 'n leërmag of die kerk, om deel te hê aan die stryd en oorwinning. Die verbondsmatige betrekking vind plaas in die genadeverbond waarvan Christus, kragtens die ewige vredeverbond, die Hoof is en waarvan die gelowiges, kragtens die ewige verkiesing, die lede of bondelinge is. Die betrekkings openbaar hom in die sogenaamde verbondseise of die roeping van die gelowiges om God te eer, stryd te voer en gedurig op bekering aan te dring (amptelik as profete, konings en priesters), en die sogenaamde vertondsbeloftes wat inhou deelgenootskap aan die oorwinning van Christus en beërwing van die koninkryk van God in die finale toetreding as burgers van die ewige regnum gloriae.

6. Die verhouding van die K.G., die kerk en die verbond t.o.v. die verworpenes.

Dit is duidelik dat die K.G. na sy praesens realiteit, reëel gesien, ook die verworpenes insluit, maar dat die verworpenes nie die ryk van heerlikheid beërf en daarvan geen deel uitmaak nie.

In hierdie praesens realiteit tree die kerk institutêr en verbondsmagtig op as 'n sigbare leërmag waarin ook beweeg die sonde en die hipokriete, terwyl ook nie almal Israel is wat Israel genoem word nie. Hierdie elemente word uitgesuiwer deur Christus by sy wederkoms, maar intussen groei die koring en die onkruid saam en is dit die mens nie gegee om die harte te oordeel en te bepaal wie uitverkore is en wie nie. 
7. Die roeping van die gelowige.

Die gelowige is verhondsmatig en kragtens die ewige verkiesing geroepe om hom by die ware kerk (instituut) te voeg omdat hy van die onsigbare kerk 'n lid is en altyd sal bly; hierin moet hy amptelik stryd voer teen die koninkryk van die satan, veral kragtens die organiese karakter van die kerk of die herstelde mensheid, en die stryd bring hom oor die ganse terrein van die K.G. en maak hom deelgenoot in die oorwinning en erfgenaam van die K.G. waarin God in der ewigheid alles en in almal is.

8. Saamvattende konklusie.

a. God is ewig koning van die ganse heelal. Sy almagtige heerskappy is nêrens uitgesluit nie.

b. Die begrip basileia tou Theou of ouranou sien op 'n bepaalde reëling van hierdie almagtige heerskappy t.o.v. die skepsel mens, naamlik: alle dinge word aan die mens onderwerp, hy heers amptelik as koning en is self vrywillig in absolute gehoorsaamheid aan God onderworpe.

c. In moedswillige ongehoorsaamheid weier die mens om koning te wees in diens van God. Daarom kon hy nie koning bly oor die werke van Gods hand nie. Hy verkoop homself — en die mensheid - aan die duiwel.

e. Op die ganse aarde was daar geen mens meer wat koning kon wees en aan God absoluut gehoorsaam kon wees nie. Die K.G. is dus nie meer op aarde nie; God trek dit in die hemel terug. Dit onderskei hom nou as die genadeheerskappy van God van die magsheerskappy van God of God se geregtigheid of toorn-heerskappp. Die K.G. is dan in die hemel; op aarde is daar stryd tussen die magsheerskappy van God en die koninkryk van die satan, en die heerskappy van God openbaar hom in toorn omdat alle mense aan die sonde en die koninkryk van die satan onderworpe is.

f. In die chaos op aarde begin God egter onmiddellik die koms van die genadeheerskappy of die K.G. weer voorberei. Hy doen dit op tweërlei wyse sover dit die mensheid betref en op grond van sy ewige en vrymagtige verkiesing:

1. Hy sluit 'n verbond met die uitverkorenes teenoor die duiwel en met uitsluiting van die verworpenes; die lyn is Adam, Noag, Abraham, Dawid, Jesus, met as uitstaande verbondsbelofte die koms van die K.G. en die oorwinning oor die heerskappy van die duiwel deur die Messiaskoning. 
2. Hy vergader 'n kerk wat instrument is tot verwesenliking van die koms van die K.G. in volkomenheid. In die O.T. is hierdie kerk ook sy volk, 'n koninkrpk wat die K.G. voorafskadu.

g. Met die koms van Christus op aarde is daar weer 'n Mens op aarde wat nie onderworpe is aan die heerskappy van die duiwel nie en wat in die weg van absolute gehoorsaamheid, kragtens sy Godheid, die genadeheerskappy van God op aarde herstel en daarom ook Koning is aan wie alles onderworpe is. So word Christus Jesus die Koning van die K.G.

Hy herstel onmiddellik die orde; in die chaos kom orde langs die weg van die verbond, geopenbaar in die vergadering van die gelowiges wat ook as sigbare instituut staan teenoor die sigbare heerskappy van die duiwel.

h. Die koms van Christus val in twee dele uiteen; dieselfde geld vir die K.G. en die oorwinning oor die satan. Ons kry met die vertikaalhorisontaal, die praesens-futurum, onvolkome-volkome, reëel-ideëel verhoudinge te doen.

i. As Koning van die K.G. is Jesus hier (sy Godheid, genade, Gees en majesteit) en nou (praesens realiteit) besig om te orden, om tot volmaaktheid te bring die genadeheerskappy van God.

j. Met die parousia (wederkoms) word dié ryk voltooi. Die grens van die ryk word finaal getrek; alle verworpenes is daaruit; satan en die antichris word van die aarde gewerp en het nêrens in die kosmos meer invloed nie; hy is eers uit die hemel op aarde gewerp en nou van die aarde af in die hel. Christus oordeel die ganse mensheid, die einde is daar, die ordening van Christus is voltooi. Die orde van God is herstel in die ganse hemel en op die ganse aarde. Die nuwe kosmos is daar, waarop en waarin God self heerskappy voer omdat Christus se ordeningstaak afgedaan is. Die ewige regnum gloriae het ingetree.

K. S. VAN WYK DE VRIES. 